\title{
PinX1: structure, regulation and its functions in cancer
}

Review

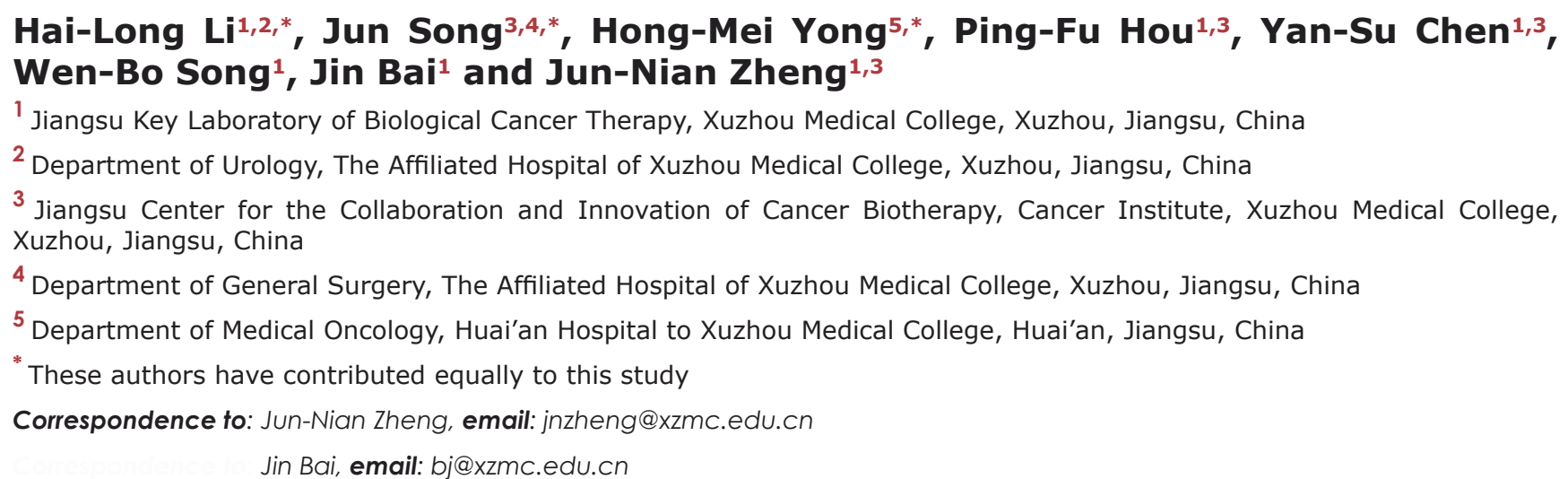
Keywords: PinX1; cancer; structure; regulation; function Received: March 14, $2016 \quad$ Accepted: August 09, $2016 \quad$ Published: August 19, 2016

\section{ABSTRACT}

PIN2/TRF1-interacting telomerase inhibitor 1 (PinX1) is a novel cloned gene located at human chromosome 8p23, playing a vital role in maintaining telomeres length and chromosome stability. It has been demonstrated to be involved in tumor genesis and progression in most malignancies. However, some researches showed opposing molecular status of PinX1 gene and its expression patterns in several other types of tumors. The pathogenic mechanism of PinX1 expression in human malignancy is not yet clear. Moreover, emerging evidence suggest that PinX1 (especially its TID domain) might be a potential new target cancer treatment. Therefore, PinX1 may be a new potential diagnostic biomarker and therapeutic target for human cancers, and may play different roles in different human cancers. The functions and the mechanisms of PinX1 in various human cancers remain unclear, suggesting the necessity of further extensive works of its role in tumor genesis and progression.

\section{TELOMERASE AND CANCER}

Telomeres are structures composed of tandem repeats of a TTAGGG sequence. They cap the ends of chromosomes, concealing them from the checkpoint responses that recognize broken DNA ends and protecting them from inappropriate exonucleolytic attack and recombination [1]. Maintaining optimal telomere length is crucial for cells. Telomerase is in the core of telomere and composed of protein and RNA components; the major being the catalytic subunit, telomerase reverse transcriptase (TERT) and telomerase RNA component (TERC or TR), which provides an associated RNA template for TERT to codes the telomere repeat. Telomerase can slow or reveres telomere shortening. In most somatic cells, telomerase is insufficient to prevent telomere shortening with cell division and advancing age [2]. Thus, following the division of somatic cells, telomeres will become critically shorten eventually, the ends of chromosomes will lost [3], cells will stop division, replicative senescence occurs [4]. However, telomerase is activated in $90 \%$ of all human cancers [5]. In cancer cells TERT is transcriptionally reactivated by the oncogenic transcription factors Myc [6], nuclear factor NF- $\mathrm{kB}$ [7], and $\beta$-catenin [8]. Thus, oncogene activation leads to telomerase activation, it enables cancer cells become replicative immortality, which is an most important hallmarks of cancer [9]. On the other hand, telomerase in general and its TERT subunit in particular can regulate other various hallmarks of cancer [10], such as regulation of sustaining proliferative signaling [11-14], modulation of angiogenesis [15-19], resistance to apoptosis [20, 21], participation of invasion and metastasis [22-24], maintaining genome stability $[25,26]$ and so on.

The ability of telomerase to elongate telomeres is regulated by a specialized protein complex, called shelterin 
or telosome, which binds to and protects telomeres at chromosome ends [27, 28]. In humans, this complex consists of six core proteins: telomeric repeat-binding factor 1 (TRF1 or TERF1) and -2 (TRF2 or TERF2), the single-stranded telomeric DNA binding protein protection of telomeres-1 (POT1), TRF1-interacting nuclear factor 2 (TIN2 or TINF2), TIN2- and POT1-organizing protein (TPP1), and transcriptional repressor/activator protein RAP1 (as known as TERF2IP) [28-30]. This complex is also able to interact with a variety of other proteins by its three telomeric DNA-binding proteins (TRF1, TRF2 and POT1), referred to as the telomere interactome, in order to fulfill their biological functions and control signaling cascades originating from telomeres $[31,32]$. TRF1 binds to double-stranded telomeric DNA and plays critical roles in telomere length regulation and telomere protection. It interacts with its associated proteins maintains telomeres at the optimal length [31, 33, 34], PIN2/TRF1-interacting telomerase inhibitor 1 (PinX1) is one of the most important protein in its associated proteins [35]. However, unlike other TRF1-binding proteins, PinX1 is unique in that it can also directly bind to TERT and TERC and inhibit telomerase activity $[35,36]$.

\section{REALIZATION TO PINX1}

PinX1 is a potent telomerase inhibitor that was first identified and characterized by Zhou et al in 2001 [35]. PinX1 is a $45-\mathrm{kDa}$ protein contains 328 amino acid (aa) in cells. The telomerase inhibitory domain (TID) is located at its C-terminal 74 aa (254-328 aa). The 254289 aa region in TID domain specifically binds to Pin2/
TRF1, this interaction plays a role in the stabilization of telomeres. The 290-328 aa region which contains a PinX1 nucleolus localization signal can associate with TERT, it is essential for the inhibition of telomerase activity [37]. Overexpression of C-terminal TID fragment has stronger depressant effect on telomerase activity in transfected cancer cells [35]. The N-terminal of PinX1 consists of a Gly-rich patch (G-patch) domain. The G-patch domain of PinX1 involves in the process of ribosomal and small nucleolar RNA maturation [38, 39], telomere metabolism [40]. Interestingly, it also has negative influence on PinX1 nucleolar localization [41]. However, it seems that PinX1 without G-patch domain has no effects on telomerase activity than entire PinX1 protein [42]. Thus, the functions of G-patch of PinX1 require thoughtful research. Between the N-terminal and C-terminal is the central section of PinX1, this domain has an effect on mediating TERT nucleolar localization [43] (Figure 1, top panel).

\section{PINX1 IS A TELOMERASE INHIBITOR ESSENTIAL FOR MAINTAINING TELOMERASE ACTIVITY AND TELOMERE LENGTH}

PinX1 can potently inhibit telomerase activation and telomeres elongation in cancer cells $[35,44]$, this ability is also conserved in yeast, rats and zebra fish [45-47]. Accumulating researches have been executed to dissect the biological function of PinX1 in regulating telomere maintenance. It has been validated that TRFH domain of TRF1 specifically recognizes a 20-amino acid sequence

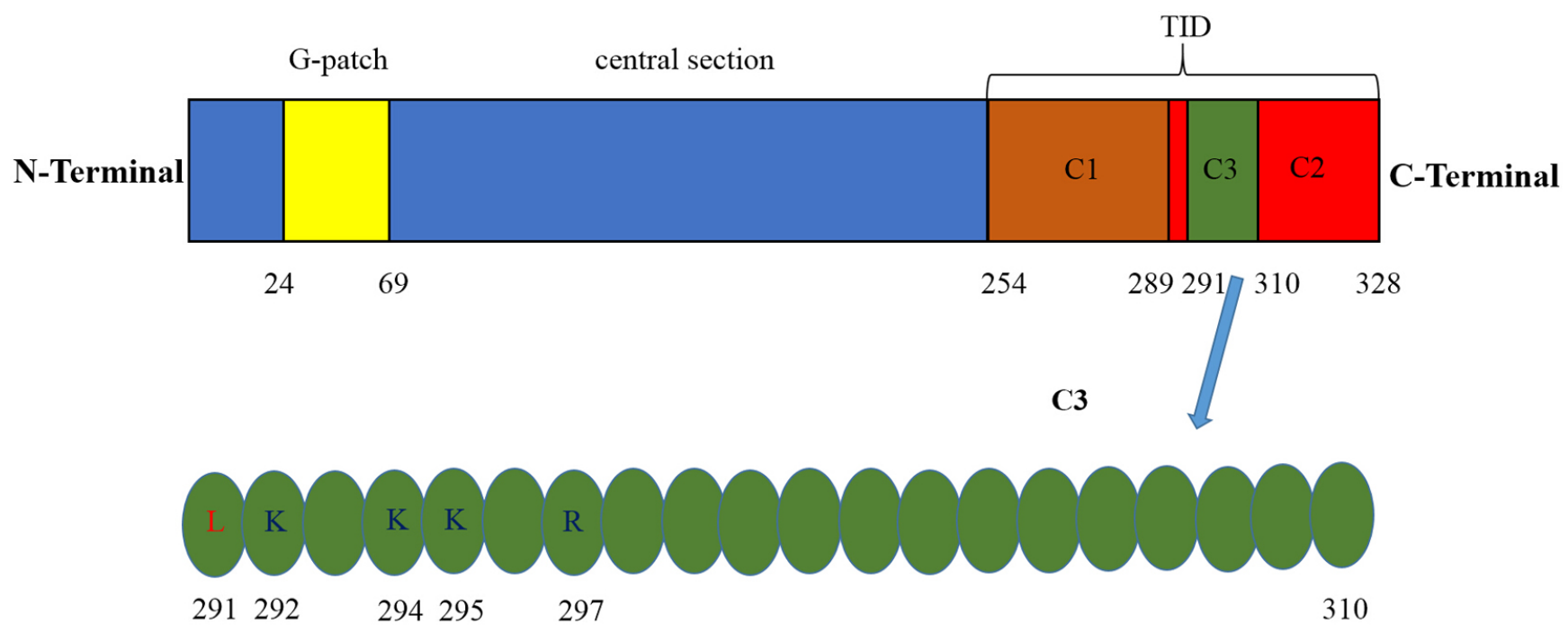

Figure 1: Identification of the main domain for the human PinX1. Top panel, G-patch domain is located at its N-terminal 46aa (24-69aa), TID domain is located at its C-terminal 74 aa (254-328 aa), C1 region of TID domain (254-289aa) specifically binds to Pin2/ TRF1, C2 region of TID domain (29-328aa) contains a PinX1 nucleolus localization signal can associate with TERT, C3 region of TID domain (291-310aa) specifically recognized by TRFH domain of TRF1 via both hydrophobic as well as hydrophilic interactions. Bottom panel, sequence of C3 fragment. PinX1-L291 is critical for the hydrophobic interaction and PinX1-K292, PinX1-K294, PinX1-K295 and PinX1-R297 are critical for the hydrophilic interaction. 
(residues 291-310) of PinX1 by both hydrophobic as well as hydrophilic interactions [48]. PinX1-L291 is critical for the hydrophobic interaction [48, 49] and PinX1-K292, PinX1-K294, PinX1-K295 and PinX1-R297 are critical for the hydrophilic interaction [48] (Figure 1, bottom panel). PinX1 likely interacts with TRF1 in both the nucleolus and the nucleoplasm, forces endogenous TRF1 accumulation in the nucleolus, increases telomere binding of TRF1 [41] and enhances TRF1 stability by inhibiting its degradation and ubiquitination [50]. TRF1-PinX1 interaction is required not only for targeting PinX1 to telomeres but also for PinX1 to prevent telomere elongation in cells. In addition, PinX1 may inhibit telomerase activity by binding to an assembled TERT-TR complex. Thus, this inhibition could occur even at the telomeres, perhaps as a means to fine-tune telomerase-dependent telomere elongation [36].

On the other hand, regulating chromosome stability is another important function of PinX1. Reducing PinX1 by gene knockout not only increases telomerase activity and telomere length, but also leads to chromosome instability in cell models [51]. However, the molecular mechanism by which reducing PinX1 function leads to chromosome instability is not clear. Therefore, further experiments are needed to define how PinX1 controls chromosome stability via telomere-dependent and/ or -independent telomerase and/or other mechanisms unrelated to telomerase [51].

\section{PINX1 AND CANCER}

PinX1 gene is localized at human chromosome 8 p23 [35, 52], which is one of the most frequent Loss of heterozygosity $(\mathrm{LOH})$ regions in human epithelial malignancies, including breast, liver, colon, lung, gastrointestinal and prostate carcinomas et al [53-67]. Moreover, PinX1 overexpression significantly suppresses the growth of hepatocellular carcinoma cells, whereas PinX1 inhibition potently enhances cell growth [52]. Depletion of PinX1 also increases tumorigenicity in nude mice [35]. Thus, PinX1 might be a putative tumor suppressor.

Tumor suppressor genes can be inactivated somatic mutation or deletion or epigenetic inactivation [9]. The mechanism for PinX1 gene inactivation in human cancers is not clear. Akiyama et al [68] examined mutations, mRNA expression and promoter methylation of PinX1 gene in 15 gastrointestinal tract carcinomas (GITC) cell lines, and 20 patients with primary GITC. Only a benign polymorphism had been found. Chang et al [69] assessed for alterations in gene sequence and transcript expression of PinX1, in a series of 52 medulloblastomas, 3 medulloblastoma cell lines and 4 primitive neuroectodermal tumors (PNETs). Direct sequence analysis of all 7 exons and splice junctions of the PinX1 gene revealed no somatic mutations but 11 genetic polymorphisms. Gregory et al [70] performed a detailed DNA sequence analysis of PinX1 in a DNA screening panel of 159 hereditary prostate cancer (HPC) families. They defined 39 polymorphisms and their frequencies in 159 HPC probands. However, PinX1 coding variants seem not be the major factors in increasing the risk for HPC. Oh et al [71] also found two missense mutations of PinX1 in hepatocellular carcinomas (HCCs) and they also revealed no relation with PinX1 expression, telomere length and telomerase activity, suggesting that they are likely polymorphisms. However, PinX1 involved in the telomere length regulation of HCCs indeed. In 2012, Min et al [72] analyzed somatic mutation of PinX1 gene in gastric, colorectal, prostate, breast, and lung carcinomas and concluded that somatic mutational events in the PinX1 may not contribute to development of these carcinomas [72]. Therefore, these combined results suggest that somatic mutation is not the mechanism for inactivation of PinX1. However, LOH of PinX1 loci was found in many carcinomas [53-67]. Thus, LOH seems play a major role in the inactivation of PinX1 in human cancers.

In 2011, Zhou et al [51] investigated that PinX1 is a major tumor suppressor. PinX1 expression is gene dosagedependent; ablation of one allele reduces protein level by $60-70 \%$ in vitro and in vivo [73], and they generated mice lacking one copy of PinX1, which yielded reduced levels of PinX1 protein, two-fold increased telomerase activity, and an approximately 50\% increase in telomere lengths in embryonic fibroblasts (MEFs) and adult tissues [2]. Moreover, PinX1 protein expressions are reduced in human breast cancer tissues and most breast carcinoma cell lines [51]. Furthermore, almost all $\mathrm{PinX}^{+/-}$mice developed increased rates of cancer, with a shift in tumor spectrum away from the lymphomas and soft tissue sarcomas typical of mice toward epithelial carcinomas more frequently developed in humans, including liver, lung, mammary, and gastrointestinal carcinomas, which are also known to have frequent $\mathrm{LOH}$ at 8p23 in humans [51]. Together all of these results indicate that PinX1 is a major tumor suppressor [51]. The mechanisms underlying it may involve telomerase activation and chromosome instability [51].

Assuming a model where the $8 \mathrm{p} 23$ region is deleted in one copy of chromosome 8 in a tumor while the remaining copy contains insufficient PinX1 for inhibiting telomerase activity, we may expect that such a tumor will exhibit higher levels of telomerase activity than normal. Ultimately, this telomerase activity increase could transform the tumor into an immortal state caused by telomere lengthening. Some results might confirm this hypothesis. Tomohiro et al [74] revealed that Reduced expression of PinX1 was detected in $68.5 \%$ cases of gastric cancer (GC). GC tissues with reduced expression of PinX1 showed significantly higher telomerase activities than those with normal expression of PinX1. LOH of 
Table 1: Clinical studies about the relationship between PinX1 and cancer

\begin{tabular}{|c|c|c|c|c|c|}
\hline $\begin{array}{l}\text { Published } \\
\text { year }\end{array}$ & Cancer type & $\begin{array}{c}\text { Cases of tumor } \\
\text { samples }\end{array}$ & $\begin{array}{|cr|}\begin{array}{l}\text { Cases } \\
\text { tumor } \\
\text { lines }\end{array} & \begin{array}{r}\text { of } \\
\text { cell }\end{array} \\
\end{array}$ & References No. & PinX1 expression \\
\hline 2011 & Breast cancer & 49 & 6 & 51 & Decreaesd \\
\hline 2005 & Gastric cancer & 73 & 7 & 74 & Decreaesd \\
\hline 2009 & Gastric cancer & 90 & No & 75 & Decreaesd \\
\hline 2010 & Ovarian carcinoma & 211 & No & 76 & Decreaesd \\
\hline 2013 & Bladder urothelial carcinoma & 187 & 3 & 77 & Decreaesd \\
\hline 2014 & Prostate cancer & 40 & No & 78 & Decreaesd \\
\hline 2015 & Clear cell renal cell carcinoma & 278 and 35 & 2 & 79 & Decreaesd \\
\hline 2015 & Breast cancer & 405 & 2 & 80 & Decreaesd \\
\hline 2013 & \begin{tabular}{|lll}
$\begin{array}{l}\text { Esophageal squamous } \\
\text { carcinoma }\end{array}$ & cell \\
\end{tabular} & 98 and 59 & No & 82 & Overexpressed \\
\hline 2014 & Cervical squamous cell carcinomas & 122 & 5 & 83 & Overexpressed \\
\hline
\end{tabular}

PinX1 locus was detected in $33.3 \%$ of 45 cases of GC and was correlated significantly with reduced expression of PinX1. Ma et al [75] reported that the frequency of $\mathrm{LOH}$ was higher in $\mathrm{GC}$ cases with lymph node metastasis than those without, and was higher in the specimens that were at TNM stage III-IV than those at stage I-II. Thus, PinX1 can be regarded as a sign of gastric cancer development. Then, increasing evidence demonstrate that PinX1 plays a key role in cancer progression. Cai et al [76] performed immunohistochemistry for PinX1 protein on a tissue microarray (TMA) of epithelial ovarian tumors and normal ovaries. They revealed that decreased expression of PinX1 was strongly related to patients with poor prognostic factors regarding presence of lymph node metastasis, distant metastasis, and late International Federation of Gynecology and Obstetrics (FIGO) stage. In univariate survival analysis, a highly significant correlation between loss of PinX1 and shortened patient survival. Liu et al [77] investigated that PinX1 expression in carcinoma of the bladder (UCB) was significantly down-regulated at both mRNA and protein level as compared with that in normal urothelial bladder epithelial tissues. PinX1 levels were inversely correlated with tumor multiplicity, advanced $\mathrm{N}$ classification, high proliferation index (Ki-67), and poor survival. Shi et al [78] reported that Reduced expression of PinX1 in prostate cancer (PCa) patients was correlated with advanced clinical stage, high Gleason score, positive regional lymph node metastasis and distant metastasis. Recent years, our research team validated that low PinX1 expression was an independent negative prognostic factor for clear cell renal cell carcinoma (ccRCC), breast cancer (BC) and gliomas patients [79-81]. These results suggest that insufficient PinX1 may involve in the progression of human cancers (Table 1).

However, some researches showed opposing molecular status of PinX1 gene and its expression patterns in other types of tumors. Qian et al [82] demonstrated that PinX1 was frequently overexpressed in esophageal squamous cell carcinoma (ESCC) tissues. The expressions of PinX1 were detected by immunohistochemistry performed in two independent cohorts of ESCC patients and by western blotting in five ESCC cell lines. Similarly, Tian et al [83] found the PinX1 expression level is upregulated in primary cervical squamous cell carcinomas (CSCC) tissues as well as in five CSCC cell lines. High expression of PinX1 was also examined over $50 \%$ of advanced CSCC patients. These suggest that the abnormalities and/or functions of PinX1 in tumour genesis and progression are complicated and may be tumor-typespecific.

The mechanism of PinX1 function in human cancer cells has yet to be fully elucidated. As we introduced previously, it was originally identified as an telomerase inhibitor and involved in maintaining telomerase activity, telomere length and chromosome stability. Besides its binding to and inhibition of telomerase, other mechanisms of these functions also been found, for example: the regulation of telomerase activity by PinX1 in gastric cancer is involved in Mad/c-Myc pathway [84], and the role of PinX1 in telomerase function regulation is mediated by cycle-dependent localization of telomerase to telomere [85]. Furthermore, PinX1 is a novel microtubulebinding protein essential for faithful chromosome segregation in mitosis. Suppression of PinX1 by siRNA abrogates faithful chromosome segregation and results in anaphase chromatid bridges in mitosis and micronuclei in interphase, suggesting an essential role of PinX1 in chromosome stability [86]. In addition, the promoter region of human PinX1 gene also had been cloned and characterized and several putative binding sites for transcription factors such as CREB, P53, E2F, GATA-

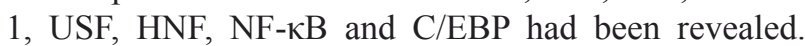
These reveals could facilitate further studies to explore the regulation and conversion mechanism of PinX1 expression during oncogenesis [87]. Recently, it was been demonstrated that PinX1 expression is directly activated by P53 in cervical cancer cells. HPV16 E6, which plays an important role in human cervical carcinogenesis [88], 
can inhibit the expression of PinX1 via suppressing P53 transcriptional activity, resulting in the enhancement of telomerase activity [89]. Our research also identified that PinX1 inhibited the migration and invasion of ccRCC cells and BC cells by suppressing MMP-2 and MMP-9 expression and activity respectively via $\mathrm{NF}-\kappa \mathrm{B}$-dependent transcription in vitro [79, 80]. It seems further works are needed to clarify the mechanisms of PinX1 in regulating tumor genesis and progression of different types of human carcinomas in detail.

\section{PINX1 IS A POTENTIAL TARGET IN CANCER THERAPY}

As a major tumor suppressor, PinX1 has been demonstrated to be a new potential target in cancer therapy. Zhou et al firstly showed that overexpression of PinX1 (especially its small TID domain) decreased cancer cells' tumorigenicity in mice [35]. In our previous study, we demonstrated that PinX1 suppresses renal cell carcinoma and breast cancer invasion and metastasis in vitro and in vivo [79, 80]. Subsequently, this result has also been confirmed in other tumor cells just like human fibrosarcoma cells, hepatocellular carcinoma cells, breast cancer cells, burkitt's lymphoma cells, nasopharyngeal carcinoma cells and esophageal cancer cells [51, 90-94]. Moreover, some researchers expanded this application to many different human cancer cells or tissues by various schleppers. Chen et al fused TID domain of PinX1 to the transactivator of transcription of human immunodeficiency virus (Tat) - an 11-amino acid peptide that translocates across the cell membrane. This purified protein was efficiently transduced into the hepatocellular carcinoma cell and hepatoblastoma cell and caused telomere shortening, limited their proliferation and inhibited growth of tumors from these cells in mice [91]. Zhang et al generated novel recombinant proteins containing mBAFF (a novel ligand for targeted therapy of $\mathrm{BAFF}$ receptor-positive malignancies), a polyarginine tract $9 \mathrm{R}$ and PinX1 (or its $\mathrm{C} / \mathrm{N}$ terminal), to target lymphoma cells. These fusion proteins specifically killed BAFF receptor-expressing Burkitt's lymphoma (BL) cells by inhibiting telomerase activity. Therapeutic experiments using fusion protein containing $\mathrm{C}$ terminal of PinX1 in SCID mice implanted with Raji cells showed significantly prolonged survival times, indicating the in vivo antitumor activity of the fusion protein. In 2014, Long et al combined doxorubicin with short interfering siRNA and a novel nanoparticle. This compound was shown to be viable for siRNA deliver into glioma cells and had more effective role in inhibiting gliomas [95]. Moreover, PinX1 overexpression could enhance the sensitivity of human gastric carcinoma cell line to 5-fluorouracil [96]. Interestingly, knockdown of PinX1 dramatically enhanced paclitaxel cytotoxicity to cervical squamous cell carcinomas cells [83] and knockdown of PinX1 substantially increased ESCC (oesophageal squamous cell carcinoma) cells' therapeutic efficacy of radiation both in vitro and in vivo.

\section{CONCLUSIONS AND OUTLOOK}

PinX1 is identified as a TRF1/Pin2-binding protein and a telomerase inhibitor originally. Then it has been demonstrated that it is essential for maintaining telomeres length and chromosome stability. Recent results have discovered that PinX1 is a major tumor suppressor and involved in tumorigenesis and tumor progression. Furthermore, emerging evidence suggest that PinX1 (especially its TID domain) might be a potential new target cancer treatment. However, many questions remained to be addressed including what are the functions of G-patch of PinX1, how PinX1 regulates tumorigenesis and tumor progression, what induce the functions of PinX1 to be tumor-type-specific, how to develop PinX1based cancer diagnosis and individualized treatment, and whether PinX1 has other new functions. Further works on this novel protein would reveal novel insight into the regulation of tumor genesis and progression and might eventually lead to new diagnosis and individualized treatment for cancers.

\section{ACKNOWLEDGMENTS}

This project is supported by grants from the National Natural Science Foundation of China (No. 81472663, 81502193), the Education Department of Jiangsu Province (No. 15KJA320006), the Science and Technology Department of Jiangsu Province (No. BK20151167).

\section{CONFLICTS OF INTEREST}

The authors have no conflicts of interest to disclose.

\section{REFERENCES}

1. Palm $\mathrm{W}$ and de Lange $\mathrm{T}$. How shelterin protects mammalian telomeres. Annual review of genetics. 2008; 42:301-334.

2. Johnson FB. PinX1 the tail on the chromosome. The Journal of clinical investigation. 2011; 121(4):1242-1244.

3. Blackburn EH. The end of the (DNA) line. Nature structural biology. 2000; 7(10):847-850.

4. Harley CB, Futcher $\mathrm{AB}$ and Greider CW. Telomeres shorten during ageing of human fibroblasts. Nature. 1990; 345(6274):458-460.

5. Shay JW and Bacchetti S. A survey of telomerase activity in human cancer. European journal of cancer. 1997; 33(5):787-791.

6. Greenberg RA, O’Hagan RC, Deng H, Xiao Q, Hann SR, Adams RR, Lichtsteiner S, Chin L, Morin GB and DePinho RA. Telomerase reverse transcriptase gene is a direct target 
of c-Myc but is not functionally equivalent in cellular transformation. Oncogene. 1999; 18(5):1219-1226.

7. Yin L, Hubbard AK and Giardina C. NF-kappa B regulates transcription of the mouse telomerase catalytic subunit. The Journal of biological chemistry. 2000; 275(47):3667136675 .

8. Zhang Y, Toh L, Lau P and Wang X. Human telomerase reverse transcriptase (hTERT) is a novel target of the Wnt/ beta-catenin pathway in human cancer. The Journal of biological chemistry. 2012; 287(39):32494-32511.

9. Hanahan D and Weinberg RA. Hallmarks of cancer: the next generation. Cell. 2011; 144(5):646-674.

10. Low $\mathrm{KC}$ and Tergaonkar V. Telomerase: central regulator of all of the hallmarks of cancer. Trends in biochemical sciences. 2013; 38(9):426-434.

11. Sarin KY, Cheung P, Gilison D, Lee E, Tennen RI, Wang E, Artandi MK, Oro AE and Artandi SE. Conditional telomerase induction causes proliferation of hair follicle stem cells. Nature. 2005; 436(7053):1048-1052.

12. Choi J, Southworth LK, Sarin KY, Venteicher AS, Ma W, Chang W, Cheung P, Jun S, Artandi MK, Shah N, Kim SK and Artandi SE. TERT promotes epithelial proliferation through transcriptional control of a Myc- and Wnt-related developmental program. PLoS genetics. 2008; 4(1):e10.

13. Smith LL, Coller HA and Roberts JM. Telomerase modulates expression of growth-controlling genes and enhances cell proliferation. Nature cell biology. 2003; 5(5):474-479.

14. Hrdlickova R, Nehyba J and Bose HR, Jr. Alternatively spliced telomerase reverse transcriptase variants lacking telomerase activity stimulate cell proliferation. Molecular and cellular biology. 2012; 32(21):4283-4296.

15. Lee SH, Kim JW, Oh SH, Kim YJ, Rho SB, Park K, Park KL and Lee JH. IFN-gamma/IRF-1-induced p27kip1 downregulates telomerase activity and human telomerase reverse transcriptase expression in human cervical cancer. FEBS letters. 2005; 579(5):1027-1033.

16. George J, Banik NL and Ray SK. Combination of hTERT knockdown and IFN-gamma treatment inhibited angiogenesis and tumor progression in glioblastoma. Clinical cancer research. 2009; 15(23):7186-7195.

17. Zhou L, Zheng D, Wang $\mathrm{M}$ and Cong YS. Telomerase reverse transcriptase activates the expression of vascular endothelial growth factor independent of telomerase activity. Biochemical and biophysical research communications. 2009; 386(4):739-743.

18. Zaccagnini G, Gaetano C, Della Pietra L, Nanni S, Grasselli A, Mangoni A, Benvenuto R, Fabrizi M, Truffa S, Germani A, Moretti F, Pontecorvi A, Sacchi A, Bacchetti S, Capogrossi MC and Farsetti A. Telomerase mediates vascular endothelial growth factor-dependent responsiveness in a rat model of hind limb ischemia. The Journal of biological chemistry. 2005; 280(15):1479014798.
19. Bermudez Y, Yang H, Saunders BO, Cheng JQ, Nicosia SV and Kruk PA. VEGF- and LPA-induced telomerase in human ovarian cancer cells is Sp1-dependent. Gynecologic oncology. 2007; 106(3):526-537.

20. Bermudez Y, Erasso D, Johnson NC, Alfonso MY, Lowell $\mathrm{NE}$ and Kruk PA. Telomerase confers resistance to caspasemediated apoptosis. Clinical interventions in aging. 2006; 1(2):155-167.

21. Indran IR, Hande MP and Pervaiz S. hTERT overexpression alleviates intracellular ROS production, improves mitochondrial function, and inhibits ROS-mediated apoptosis in cancer cells. Cancer research. 2011; 71(1):266276.

22. Liu Z, Li Q, Li K, Chen L, Li W, Hou M, Liu T, Yang J, Lindvall C, Bjorkholm M, Jia J and Xu D. Telomerase reverse transcriptase promotes epithelial-mesenchymal transition and stem cell-like traits in cancer cells. Oncogene. 2013; 32(36):4203-4213.

23. Huber MA, Azoitei N, Baumann B, Grunert S, Sommer A, Pehamberger H, Kraut N, Beug H and Wirth T. NFkappaB is essential for epithelial-mesenchymal transition and metastasis in a model of breast cancer progression. The Journal of clinical investigation. 2004; 114(4):569-581.

24. Fukuyama R, Ng KP, Cicek M, Kelleher C, Niculaita R, Casey G and Sizemore N. Role of IKK and oscillatory NFkappaB kinetics in MMP-9 gene expression and chemoresistance to 5-fluorouracil in RKO colorectal cancer cells. Molecular carcinogenesis. 2007; 46(5):402-413.

25. Artandi SE and DePinho RA. Telomeres and telomerase in cancer. Carcinogenesis. 2010; 31(1):9-18.

26. Masutomi K, Possemato R, Wong JM, Currier JL, Tothova Z, Manola JB, Ganesan S, Lansdorp PM, Collins K and Hahn WC. The telomerase reverse transcriptase regulates chromatin state and DNA damage responses. Proceedings of the National Academy of Sciences of the United States of America. 2005; 102(23):8222-8227.

27. Smogorzewska A and de Lange T. Regulation of telomerase by telomeric proteins. Annual review of biochemistry. 2004; 73:177-208.

28. Verdun RE and Karlseder J. Replication and protection of telomeres. Nature. 2007; 447(7147):924-931.

29. Cech TR. Beginning to understand the end of the chromosome. Cell. 2004; 116(2):273-279.

30. Songyang $\mathrm{Z}$ and Liu D. Inside the mammalian telomere interactome: regulation and regulatory activities of telomeres. Critical reviews in eukaryotic gene expression. 2006; 16(2):103-118.

31. de Lange T. Shelterin: the protein complex that shapes and safeguards human telomeres. Genes \& development. 2005; 19(18):2100-2110.

32. Robles-Espinoza CD, Del Castillo Velasco-Herrera M, Hayward NK and Adams DJ. Telomere-regulating Genes and the Telomere Interactome in Familial Cancers. Molecular cancer research. 2014. 
33. van Steensel B, Smogorzewska A and de Lange T. TRF2 protects human telomeres from end-to-end fusions. Cell. 1998; 92(3):401-413.

34. van Steensel B and de Lange T. Control of telomere length by the human telomeric protein TRF1. Nature. 1997; 385(6618):740-743.

35. Zhou XZ and Lu KP. The Pin2/TRF1-interacting protein PinX1 is a potent telomerase inhibitor. Cell. 2001; 107(3):347-359.

36. Banik SS and Counter CM. Characterization of interactions between PinX1 and human telomerase subunits hTERT and hTR. The Journal of biological chemistry. 2004; 279(50):51745-51748.

37. Chen G, Da L, Xu Y, Xu M, Song L, Li T and Zhao M. C-terminal amino acids 290-328 of LPTS/PinX1 confer telomerase inhibition. Biochemical and biophysical research communications. 2010; 398(4):683-689.

38. Guglielmi B and Werner M. The yeast homolog of human PinX1 is involved in rRNA and small nucleolar RNA maturation, not in telomere elongation inhibition. The Journal of biological chemistry. 2002; 277(38):3571235719 .

39. Chen YL, Capeyrou R, Humbert O, Mouffok S, Kadri YA, Lebaron S, Henras AK and Henry Y. The telomerase inhibitor Gnolp/PINX1 activates the helicase Prp43p during ribosome biogenesis. Nucleic acids research. 2014; 42(11):7330-7345.

40. Herrmann G, Kais S, Hoffbauer J, Shah-Hosseini K, Bruggenolte N, Schober H, Fasi M and Schar P. Conserved interactions of the splicing factor Ntr1/Spp382 with proteins involved in DNA double-strand break repair and telomere metabolism. Nucleic acids research. 2007; 35(7):23212332.

41. Yoo JE, Oh BK and Park YN. Human PinX1 mediates TRF1 accumulation in nucleolus and enhances TRF1 binding to telomeres. Journal of molecular biology. 2009; 388(5):928-940.

42. Zhang R, Zhao J, Wang X, Wang LL, Xu J and Song C. PinX1 without the G-patch motif suppresses proliferation, induces senescence, but does not inhibit telomerase activity in colorectal cancer SW480 cells. Oncology reports. 2014; 32(1):286-292.

43. Lin J, Jin R, Zhang B, Yang PX, Chen H, Bai YX, Xie Y, Huang $\mathrm{C}$ and Huang J. Characterization of a novel effect of hPinX1 on hTERT nucleolar localization. Biochemical and biophysical research communications. 2007; 353(4):946952.

44. Liao C, Zhao MJ, Zhao J, Jia D, Song H and Li ZP. Over-expression of LPTS-L in hepatocellular carcinoma cell line SMMC-7721 induces crisis. World journal of gastroenterology. 2002; 8(6):1050-1052.

45. Lin $J$ and Blackburn EH. Nucleolar protein PinX1p regulates telomerase by sequestering its protein catalytic subunit in an inactive complex lacking telomerase RNA.
Genes \& development. 2004; 18(4):387-396.

46. Oh BK, Yoon SM, Lee CH and Park YN. Rat homolog of PinX1 is a nucleolar protein involved in the regulation of telomere length. Gene. 2007; 400(1-2):35-43.

47. Sun $\mathrm{C}, \mathrm{Wu} \mathrm{Z}$, Jia F, Wang $\mathrm{Y}$, Li $\mathrm{T}$ and Zhao $\mathrm{M}$. Identification of zebrafish LPTS: a gene with similarities to human LPTS/PinX1 that inhibits telomerase activity. Gene. 2008; 420(1):90-98.

48. Soohoo CY, Shi R, Lee TH, Huang P, Lu KP and Zhou XZ. Telomerase inhibitor PinX1 provides a link between TRF1 and telomerase to prevent telomere elongation. The Journal of biological chemistry. 2011; 286(5):3894-3906.

49. Chen Y, Yang Y, van Overbeek M, Donigian JR, Baciu P, de Lange $T$ and Lei M. A shared docking motif in TRF1 and TRF2 used for differential recruitment of telomeric proteins. Science. 2008; 319(5866):1092-1096.

50. Yoo JE, Park YN and Oh BK. PinX1, a telomere repeatbinding factor 1 (TRF1)-interacting protein, maintains telomere integrity by modulating TRF1 homeostasis, the process in which human telomerase reverse Transcriptase (hTERT) plays dual roles. The Journal of biological chemistry. 2014; 289(10):6886-6898.

51. Zhou XZ, Huang P, Shi R, Lee TH, Lu G, Zhang Z, Bronson $\mathrm{R}$ and $\mathrm{Lu} \mathrm{KP}$. The telomerase inhibitor PinX1 is a major haploinsufficient tumor suppressor essential for chromosome stability in mice. The Journal of clinical investigation. 2011; 121(4):1266-1282.

52. Liao C, Zhao M, Song H, Uchida K, Yokoyama KK and $\mathrm{Li} \mathrm{T}$. Identification of the gene for a novel liver-related putative tumor suppressor at a high-frequency loss of heterozygosity region of chromosome 8 p23 in human hepatocellular carcinoma. Hepatology. 2000; 32(4 Pt 1):721-727.

53. Emi M, Fujiwara Y, Nakajima T, Tsuchiya E, Tsuda H, Hirohashi S, Maeda Y, Tsuruta K, Miyaki M and Nakamura Y. Frequent loss of heterozygosity for loci on chromosome $8 \mathrm{p}$ in hepatocellular carcinoma, colorectal cancer, and lung cancer. Cancer research. 1992; 52(19):5368-5372.

54. Becker SA, Zhou YZ and Slagle BL. Frequent loss of chromosome $8 \mathrm{p}$ in hepatitis B virus-positive hepatocellular carcinomas from China. Cancer research. 1996; 56(21):5092-5097.

55. Nagai H, Pineau P, Tiollais P, Buendia MA and Dejean A. Comprehensive allelotyping of human hepatocellular carcinoma. Oncogene. 1997; 14(24):2927-2933.

56. Pineau $P$, Nagai $H$, Prigent $S$, Wei Y, Gyapay G, Weissenbach J, Tiollais P, Buendia MA and Dejean A. Identification of three distinct regions of allelic deletions on the short arm of chromosome 8 in hepatocellular carcinoma. Oncogene. 1999; 18(20):3127-3134.

57. Wong N, Lai P, Pang E, Fung LF, Sheng Z, Wong V, Wang W, Hayashi Y, Perlman E, Yuna S, Lau JW and Johnson PJ. Genomic aberrations in human hepatocellular carcinomas of differing etiologies. Clinical cancer research. 2000; 
6(10):4000-4009.

58. Yokota T, Yoshimoto M, Akiyama F, Sakamoto G, Kasumi F, Nakamura Y and Emi M. Localization of a tumor suppressor gene associated with the progression of human breast carcinoma within a 1-cM interval of 8p22-p23.1. Cancer. 1999; 85(2):447-452.

59. Wang JC, Radford DM, Holt MS, Helms C, Goate A, Brandt W, Parik M, Phillips NJ, DeSchryver K, Schuh ME, Fair KL, Ritter JH, Marshall P and Donis-Keller H. Sequence-ready contig for the 1.4-cM ductal carcinoma in situ loss of heterozygosity region on chromosome 8p22-p23. Genomics. 1999; 60(1):1-11.

60. Loo LW, Grove DI, Williams EM, Neal CL, Cousens LA, Schubert EL, Holcomb IN, Massa HF, Glogovac J, Li CI, Malone KE, Daling JR, Delrow JJ, Trask BJ, Hsu L and Porter PL. Array comparative genomic hybridization analysis of genomic alterations in breast cancer subtypes. Cancer research. 2004; 64(23):8541-8549.

61. Bhattacharya N, Chunder N, Basu D, Roy A, Mandal S, Majumder J, Roychowdhury S and Panda CK. Three discrete areas within the chromosomal 8p21.3-23 region are associated with the development of breast carcinoma of Indian patients. Experimental and molecular pathology. 2004; 76(3):264-271.

62. Varma G, Varma R, Huang H, Pryshchepava A, Groth J, Fleming D, Nowak NJ, McQuaid D, Conroy J, Mahoney M, Moysich K, Falkner KL and Geradts J. Array comparative genomic hybridisation (aCGH) analysis of premenopausal breast cancers from a nuclear fallout area and matched cases from Western New York. British journal of cancer. 2005; 93(6):699-708.

63. Kishimoto Y, Shiota G, Wada K, Kitano M, Nakamoto K, Kamisaki Y, Suou T, Itoh T and Kawasaki H. Frequent loss in chromosome $8 \mathrm{p}$ loci in liver cirrhosis accompanying hepatocellular carcinoma. Journal of cancer research and clinical oncology. 1996; 122(10):585-589.

64. Baffa R, Santoro R, Bullrich F, Mandes B, Ishii H and Croce CM. Definition and refinement of chromosome $8 p$ regions of loss of heterozygosity in gastric cancer. Clinical cancer research. 2000; 6(4):1372-1377.

65. Gustafson CE, Wilson PJ, Lukeis R, Baker E, Woollatt E, Annab L, Hawke L, Barrett JC and ChenevixTrench G. Functional evidence for a colorectal cancer tumor suppressor gene at chromosome $8 \mathrm{p} 22-23$ by monochromosome transfer. Cancer research. 1996; 56(22):5238-5245.

66. Wong MP, Lam WK, Wang E, Chiu SW, Lam CL and Chung LP. Primary adenocarcinomas of the lung in nonsmokers show a distinct pattern of allelic imbalance. Cancer research. 2002; 62(15):4464-4468.

67. Wang Z and Lai FM. [Analysis of loss of heterozygosity on chromosome 8 in human prostate carcinoma and high grade prostatic intraepithelial neoplasia]. National journal of andrology. 2004; 10(1):26-28, 31.
68. Akiyama Y, Maesawa C, Wada K, Fujisawa K, Itabashi T, Noda Y, Honda T, Sato N, Ishida K, Takagane A, Saito K and Masuda T. Human PinX1, a potent telomerase inhibitor, is not involved in human gastrointestinal tract carcinoma. Oncology reports. 2004; 11(4):871-874.

69. Chang Q, Pang JC, Li J, Hu L, Kong X and Ng HK. Molecular analysis of PinX1 in medulloblastomas. International journal of cancer. 2004; 109(2):309-314.

70. Hawkins GA, Chang BL, Zheng SL, Isaacs SD, Wiley KE, Bleecker ER, Walsh PC, Meyers DA, Xu J and Isaacs WB. Mutational analysis of PINX1 in hereditary prostate cancer. The Prostate. 2004; 60(4):298-302.

71. Oh BK, Chae KJ, Park C and Park YN. Molecular analysis of PinX1 in human hepatocellular carcinoma. Oncology reports. 2004; 12(4):861-866.

72. Kim MS, Kim SS, Yoo NJ and Lee SH. Somatic mutation of PINX1 gene is rare in common solid cancers. APMIS. 2012; 120(9):770-771.

73. Zhou XZ. PinX1: a sought-after major tumor suppressor at human chromosome 8p23. Oncotarget. 2011; 2(10):810819. doi:10.18632/oncotarget.339.

74. Kondo T, Oue N, Mitani Y, Kuniyasu H, Noguchi T, Kuraoka K, Nakayama $\mathrm{H}$ and Yasui W. Loss of heterozygosity and histone hypoacetylation of the PINX1 gene are associated with reduced expression in gastric carcinoma. Oncogene. 2005; 24(1):157-164.

75. Ma Y, Wu L, Liu C, Xu L, Li D and Li JC. The correlation of genetic instability of PINX1 gene to clinico-pathological features of gastric cancer in the Chinese population. Journal of cancer research and clinical oncology. 2009; 135(3):431437.

76. Cai MY, Zhang B, He WP, Yang GF, Rao HL, Rao ZY, Wu QL, Guan XY, Kung HF, Zeng YX and Xie D. Decreased expression of PinX1 protein is correlated with tumor development and is a new independent poor prognostic factor in ovarian carcinoma. Cancer science. 2010; 101(6):1543-1549.

77. Liu JY, Qian D, He LR, Li YH, Liao YJ, Mai SJ, Tian XP, Liu YH, Zhang JX, Kung HF, Zeng YX, Zhou FJ and Xie D. PinX1 suppresses bladder urothelial carcinoma cell proliferation via the inhibition of telomerase activity and p16/cyclin D1 pathway. Molecular cancer. 2013; 12(1):148.

78. Shi R, Zhao Z, Zhou H, Wei M, Ma WL, Zhou JY and Tan WL. Reduced expression of PinX1 correlates to progressive features in patients with prostate cancer. Cancer cell international. 2014; 14:46.

79. Li HL, Han L, Chen HR, Meng F, Liu QH, Pan ZQ, Bai $\mathrm{J}$ and Zheng JN. PinX1 serves as a potential prognostic indicator for clear cell renal cell carcinoma and inhibits its invasion and metastasis by suppressing MMP-2 via NF-kappaB-dependent transcription. Oncotarget. 2015; 6(25):21406-21420. doi: 10.18632/oncotarget.401.

80. Shi M, Cao M, Song J, Liu Q, Li H, Meng F, Pan Z, Bai J and Zheng J. PinX1 inhibits the invasion and metastasis of 
human breast cancer via suppressing NF-kappaB/MMP-9 signaling pathway. Molecular cancer. 2015; 14:66.

81. Bai J, Chen YS, Mei PJ, Liu QH, Du Y and Zheng JN. PinX1 is up-regulated and associated with poor patients' survival in gliomas. Int J Clin Exp Pathol. 2015; 8(6):69526959.

82. Qian D, Zhang B, He LR, Cai MY, Mai SJ, Liao YJ, Liu YH, Lin MC, Bian XW, Zeng YX, Huang JJ, Kung $\mathrm{HF}$ and Xie D. The telomere/telomerase binding factor PinX1 is a new target to improve the radiotherapy effect of oesophageal squamous cell carcinomas. The Journal of pathology. 2013; 229(5):765-774.

83. Tian XP, Qian D, He LR, Huang H, Mai SJ, Li CP, Huang XX, Cai MY, Liao YJ, Kung HF, Zeng YX and Xie D. The telomere/telomerase binding factor PinX1 regulates paclitaxel sensitivity depending on spindle assembly checkpoint in human cervical squamous cell carcinomas. Cancer letters. 2014; 353(1):104-114.

84. Wang HB, Wang XW, Zhou G, Wang WQ, Sun YG, Yang SM and Fang DC. PinX1 inhibits telomerase activity in gastric cancer cells through Mad1/c-Myc pathway. Journal of gastrointestinal surgery. 2010; 14(8):1227-1234.

85. Cheung DH, Kung HF, Huang JJ and Shaw PC. PinX1 is involved in telomerase recruitment and regulates telomerase function by mediating its localization. FEBS letters. 2012; 586(19):3166-3171.

86. Yuan K, Li N, Jiang K, Zhu T, Huo Y, Wang C, Lu J, Shaw A, Thomas K, Zhang J, Mann D, Liao J, Jin C and Yao X. $\mathrm{PinX} 1$ is a novel microtubule-binding protein essential for accurate chromosome segregation. The Journal of biological chemistry. 2009; 284(34):23072-23082.

87. Wang S, Liao $\mathrm{C}, \mathrm{Li} \mathrm{T}$ and Zhao M. Cloning and characterization of the promoter region of human LPTS/ PinX1 gene. Biochimica et biophysica acta. 2004; 1676(3):261-265.

88. Jay N and Moscicki AB. Human papillomavirus infections in women with HIV disease: prevalence, risk, and management. The AIDS reader. 2000; 10(11):659-668.
89. Wu G, Liu D, Jiang K, Zhang L, Zeng Y, Zhou P, Zhong D, Gao M, He F and Zheng Y. PinX1, a novel target gene of p53, is suppressed by HPV16 E6 in cervical cancer cells. Biochimica et biophysica acta. 2014; 1839(2):88-96.

90. Zhang B, Bai YX, Ma HH, Feng F, Jin R, Wang ZL, Lin J, Sun SP, Yang P, Wang XX, Huang PT, Huang CF, Peng Y, Chen YC, Kung HF and Huang JJ. Silencing PinX1 compromises telomere length maintenance as well as tumorigenicity in telomerase-positive human cancer cells. Cancer research. 2009; 69(1):75-83.

91. Chen G, Da L, Wang H, Xu Y, Chen G, Sun C, Wang L, Zhao J, Zhang F, Feng J, Wang Y, Tiollais P, Li T and Zhao M. HIV-Tat-mediated delivery of an LPTS functional fragment inhibits telomerase activity and tumorigenicity of hepatoma cells. Gastroenterology. 2011; 140(1):332-343.

92. Zhang L, Jiang Y, Zheng Y, Zeng Y, Yang Z, Huang G, Liu D, Gao M, Shen X, Wu G, Yan X and He F. Selective killing of Burkitt's lymphoma cells by mBAFF-targeted delivery of PinX1. Leukemia. 2011; 25(2):331-340.

93. Lai XF, Shen CX, Wen Z, Qian YH, Yu CS, Wang JQ, Zhong PN and Wang HL. PinX1 regulation of telomerase activity and apoptosis in nasopharyngeal carcinoma cells. Journal of experimental \& clinical cancer research. 2012; $31: 12$.

94. Zuo J, Wang DH, Zhang YJ, Liu L, Liu FL and Liu W. Expression and mechanism of PinX1 and telomerase activity in the carcinogenesis of esophageal epithelial cells. Oncology reports. 2013; 30(4):1823-1831.

95. Long L, Wang W, Cai XD, Cheng D, Shuai X and Peng Y. PinX1-siRNA/mPEG-PEI-SPION combined with doxorubicin enhances the inhibition of glioma growth. Experimental and therapeutic medicine. 2014; 7(5):11701176.

96. Wang HB, Wang WQ, Wang XW, Sun YG, Zhou G, Yang $\mathrm{SM}$ and Fan DC. PinX1 gene transfection enhances the sensitivity of gastric carcinoma cell line to 5-fluorouracil. Hepato-gastroenterology. 2011; 58(106):682-686. 